\title{
Excess weight and factors associated in preschool of southwest of Bahia
}

\author{
Andressa Tavares Gomes 1 \\ Taiane Gonçalves Novaes 2 \\ Karine Chagas Silveira 3 \\ Cláudio Lima Souza 4 \\ Joel Alves Lamounier 5 \\ Michele Pereira Netto 6 \\ Flávio Diniz Capanema 7 \\ Daniela da Silva Rocha 8
}

\begin{abstract}
1,2,3,4,8 Instituto Multidisciplinar em Saúde. Universidade Federal da Bahia. Campus Anísio Teixeira. Rua Rio de Contas, 58. Candeias. Vitória da Conquista, BA, Brasil. CEP: 45.029-094. E-mail: drochaufba@gmail.com

5 Universidade Federal de São João del-Rei. São João del-Rei, MG, Brasil.

6 Departamento de Nutrição. Instituto de Ciências Biológicas. Universidade Federal de Juiz de Fora. Juiz de Fora, MG, Brasil.

7 Fundação Hospitalar do Estado de Minas Gerais. Belo Horizonte, MG, Brasil.
\end{abstract}

\begin{abstract}
Objectives: this study aimed to evaluate the environmental factors associated with excess weight in preschool children.

Methods: a cross-sectional study involving 664 full-time preschoolers enrolled in public childcare centers in Vitória da Conquista (BA). The excess weight status has been defined according to the BMI/Age index and score $Z$ above +2 . The independent variables were grouped into maternal characteristics, socioeconomic, related to children and child care. We conducted multiple logistic regression to assess the association between excess weight and the variables studied.

Results: a prevalence of excess weight was $5.7 \% ; 3.9 \%$ were overweight and $1.8 \%$ were obese. The factors associated with excess weight in children were cesarean delivery (OR: 2.59; IC95\%: 1.11; 6.01); being singletons (OR: 3.32; IC95\%: 1.44; 7.67); and exclusive breastfeeding of less than 4 months (OR: 2.59; IC95\%: 1.12; 5.99).

Conclusions: the results show that interventions to reduce and/or prevent excess weight should begin prenatally, with promotion of exclusive breastfeeding and natural birth, as well as nutritional advice for mothers with singletons.
\end{abstract}

Key words Child, Preschool, Breast Feeding, Cesarean section, Overweight, Obesity 


\section{Introduction}

In the last decades, significant changes occurred in the nutritional children panorama, characterized by the increase of Excess Weight (EW), a disorder which includes overweight and obesity. ${ }^{1}$

In 20 years, (1990 to 2010) the prevalance of overweight in preschool children went from $4.2 \%$ for $6.7 \%$, which represents a relative increase of $60 \% .{ }^{1}$ Thus, the children's EW has been showing epidemic proportion, affecting families who have low-income. ${ }^{2}$ In regard of preschool obesity, it is estimated a prevalence of $9.1 \%$ for $2020 .{ }^{2}$ In Brazil, this panororama is not different, for the prevalence of EW in children increased $160 \%$ in 17 years, reaching the Northeast region of this country $(20.6 \%$ for each year) ${ }^{3}$

The EW in children is considered a serious public health problem, because leads to development of health problems (morbid conditions, lung diseases, as well as cardiovascular, endocrine, orthopedic and psychosocial ones). 4 Several studies showed that children who have EW evolve with the same nutritional disorder in adulthood and has a high risk to develop cardiovascular diseases and type II diabetes mellitus.3,4

For the etiology of EW in childhood, studies seek to elucidate the genetic, physiological, metabolic, environmental and behavioral risk factors involved in its genesis.5,6 Although children live now in more "obesogenic" envioronment than they did in the past, not all children develop EW. Therefore, it is necessary to understand how individuals interact with their environment and how these risk factors interrelate. 7 Others risk factors such as high birth weight, 6 inadequate breastfeeding, ${ }^{8}$ weight gain in pregnancy, ${ }^{9}$ effective maternal schooling 5 and singletons ${ }^{3}$ are also associated with EW in childhood.

Although the data showed significant for EW in childhood, there are only a few studies who discuss about this problem in preschool children from poor regions of the country due to the greater focus of research on nutritional deficiencies. ${ }^{5}$ Whereas children in the northeast region of the country are also exposed to the risk factors for EW, this study aimed to evaluate the prevalence and factors associated with EW in preschool children enrolled in public day care centers.

\section{Methods}

This is a cross-seccional study which was part of a larger study entitled "Characterization of the health and nutrition situation of children assisted in municipal public day care centers to the City Hall in the city of Vitória da Conquista, BA", which objective was to evaluate the prevalence of anemia, intestinal parasitoses and nutritional changes in children enrolled full-time at all public day care centers in the city. The study was carried in all public day care centers ( 21 day care centers) in the urban to the City Hall of Vitória da Conquista, in the period of 2010 to 2012.

The day care centers attend children with 24 to 72 months; children with 24 to 60 months stay in day care centers in full-time, while older children stay half of day. The public day care is municipal responsible, while the affiliated ones are managed by philanthropic institutions that receive from the city hall food and employees.

The municipality of Vitória da Conquista, located in the Southwest of Bahia and according to IBGE data (Brazilian Institute of Geography and Statistics), 10 has a territorial area of $3,356,886 \mathrm{~km}^{2}$ and population of 306,866 inhabitants, constituting the third largest city of the State.

For the calculation of the sample it was taken the maximum prevalence estimate $(50 \%)$, because it was a broad project, encompassing several outcomes to be studied. Besides, it was considered the full number of preschool enrolled fulltime in 21 day care centers (1726 children), with precision of $5 \%$ and a $95 \%$ of confidence interval, resulting 378 subjects. However, it was analyzed data from 664 children.

The sample size was selected by the random number draw, with Microsoft Excel $2007{ }^{\circledR}$ program, adopting the following inclusion criteria: age lower than 60 months and children enrolled in day care centers full time that did not present a previous diagnosis of chronic disease.

The data were collected by nutrition students, previously trained for applying the structured questionnaire and collecting the anthropometric measurements. The structured questionnaire was applied with children's parents or guardians, containing information about child's health, family's socioeconomic conditions, maternal information and related to the day care center. The data were collected in meetings held in day-care centers with those guardian children. The studied variables present a different sample size, because the interviewees did not always know some questions or the mother and/or guardians were absent in day to applied the questionnaire.

The anthropometric measurements of weight and height was performed using standardized norms, according to the procedures established by the 
Sistema de Vigilância Alimentar e Nutricional (SISVAN) do Ministério da Saúde (Nutritional and Food Surveilance Systen of the Minstery of Health). ${ }^{11}$ To obtain body weight, it was necessary Marte ${ }^{\circledR}$, an electronic scale capacity to weigh (Manufacturer: Minas Gerais, Brazil), capacity of $200 \mathrm{~kg}$ and its sensitivity of $50 \mathrm{~g}$. The height was verified using a portable stadiometer, Alturexata ${ }^{\circledR}$ (Manufacturer: Minas Gerais, Brazil) $(213 \mathrm{~cm}$ and $1 \mathrm{~mm}$ of accuracy).

To obtain the nutritional status, it was used the growth curves of the World Health Organization (WHO), with the help of the WHO Anthro software version 3.2.2 (Manufacturer: Geneva, Switzerland). ${ }^{12}$ The nutritional status of children was classified by Body Mass Index/Age (BMI/A), expressed as $\mathrm{Z}$ score. Cut-off point established for $\mathrm{BMI} / \mathrm{A}>+2 \mathrm{e} \leq+3 \mathrm{z}$ score for overweight, $>+3 \mathrm{z}$ score for obesity. 13

Children's food consumption was performed by directly using the Marte ${ }^{\circledR}$ food scale, dish weighing offered during three non-consecutive days in all the day care centers. The food was offered for individuals dishes, properly identified. The food preparation was weighed before. Weighing leftovers and seconds of each dish were noted and the portioning was performed. It was assessed on centesimal composition of energy and macronutrients (carbohydrate, lipid and protein), through by Avanutri software (Manufacturer: Rio de Janeiro, Brazil) version 3.1.4. The adequacy of food intake was calculated on the basis of the Conselho Deliberativo do Fundo Nacional de Desenvolvimento da Educação - (CD(Deliberation counseling fund) (FNDE - National Education Development) Resolution/CD/FNDE number 26, of june 17, 201314 which recommends $70 \%$ of daily requirements of nutrients for children attending full-time basis, to calculate the adequacy divided in age groups: 1 to 3 years and 4 to 5 years.

Considered children with excess weight (dependent variable) when presented $\mathrm{Z}$ score $>+2 \mathrm{Z}$ score. Thus, in this category it was included all children with overweight and obesity.

The independent variables were grouped in maternal and socioeconomic characteristics: maternal age in the interview moment, categorized into two age groups ( $<20 \mathrm{e} \geq 20$ years); 15 matrimonial status (with or no husband/partner); number of children ( 1 and 2 or more children);16 maternal and paternal schooling in full years of study, grouped in $<8$ e $\geq 8$ years; 17 family income in minimum wages or salaries (MS) and subdivided into $\leq 1$ and $>1 \mathrm{MS}$ (value $\mathrm{R} \$ 510.00$ reais). The variables related children were: age in months, categorized into two age groups (24 to 36 incomplete months and 36 months to 60 months); 15 gender; ethnicity referred by the mother (white and non-white); type of delivery (vaginal and cesarean section); birth weight (< $4,000 \mathrm{~g}$ and $\geq 4,000 \mathrm{~g}$ ); 18 received breastfeeding (yes or no); time to exclusive breastfeeding ( $<4$ months and $\geq 4$ months). ${ }^{19}$ In relation to the variables related to day-care centers, were studied (if the children enrolled in a public or affiliated day care); age from children who attended day care center $(\leq 12$ months and $>12$ months) and the adequacy of food intake, energy, lipid, carbohydrate and protein offered in day care ( $\leq 100 \%$ and $>100 \%$ recommendation). The variable categorized was performed using previous references for comparison and distribution from the mean and quartiles.

The software employed in the statistical analysis was Statistical Package for the Social Sciences (SPSS) version 17.0 (manufacturer: New York, United States). The normality Kolmogorov Smirnov test was performed for evaluation the distribution of numerical data. The magnitude of association between risk factors and $\mathrm{EW}$ is expressed as odds ratios (OR) and its respective confidence intervals ( $95 \%$ CI). Initially, it was considered to use the bivariate analysis for evaluating the possible associations between independent variables with $\mathrm{EW}$ in childhood. Thereafter, the variables with $p \leq 0.20$ value were selected in the bivariate analysis, because they are potential confounders; Then the multiple analysis was performed using the logistic regression, removing the least significant variables until adjustment of the final model containing all significant independent variables. $(p<0.05)$, associated with EW. To assess the adequacy of the multivariate model, the Hosmer and Lemeshow test was used, which showed a value of $p$ equal to 0.798 .

This study was approved by the Ethics Committee on Human Research, at State University of Bahia Southeast, protocol number: 130/2009. The children's parents or guardians were informed about the objectives of the study and agreed to participate, having signed the Informed Consent. After data collection, all parents and/or guardians were informed of the nutritional diagnosis, and those children who presented nutritional deviations were referred to the health units.

\section{Results}

This study was composed with 664 children, aged between 24 to 60 months and average of $40.7 \pm 7.2$ months, prevailing male gender (51.2\%). Approximately a quarter of the children were born 
with cesarean section. Regarding maternal characteristics, the average age was $27.2 \pm 61$ years old and the majority $(65.9 \%)$ lived with their husband/partner. Almost half of families (47\%) received less than the minimum wage, the income varied of $R \$ 44.00$ to $R \$ 2,180.00$ reais, with median of $\mathrm{R} \$ 510.00$ reais. As to schooling time, the majority of mothers (57.4\%) and fathers $(64.0 \%)$ had less than eight years.

As for children food consumption, it was observed that $44.7 \%$ of lipids, $74.8 \%$ of proteins and $49.8 \%$ of carbohydrates were above the recommendations.

The EW prevalence were $5.7 \%$. These, $3.9 \%$ were overweight and $1.8 \%$ were obese.

Based on the bivariate analysis, among the maternal and socioeconomic characteristics related to $\mathrm{EW}$, the variables included in multiple logistic regression were: matrimonial status, number of children and family income (Tabela 1); among variables related to the children it was included: delivery type and exclusive breastfeeding duration (Tabela 2 ) and among variables related to the day care center, only type of day care was included (Tabela 3). After the multivariate analysis regression, the indenpendent risk factors associated with EW: children was born cesarean delivery, singletons and exclusive breastfeeding less than 4 months (Tabela 4).

Table 1

Prevalence of EW and Odds Ratio (OR) according to maternal and socioeconomic variables in preschool children attended in full-time at day care center $(n=664)$ in Vitória da Conquista, Bahia,Brazil, 2010 to 2012.

\begin{tabular}{|c|c|c|c|c|c|c|}
\hline Variable & $\mathbf{N}$ & $\%$ & Excess Weight (\%) & OR gross & Cl95\% & $p$ \\
\hline Mother's age (years) & & & & & $0.21-1.77$ & 0.36 \\
\hline$<20$ & 103 & 16.6 & 3.9 & 0.62 & & \\
\hline$\geq 20$ & 519 & 83.4 & 6.2 & 1 & & \\
\hline Matrimonial status & & & & & $0.24-1.19$ & 0.13 \\
\hline No husband/partner & 215 & 34.1 & 3.7 & 0.53 & & \\
\hline With husband/partner & 416 & 65.9 & 6.7 & 1 & & \\
\hline Number of children & & & & & $1.25-4.90$ & 0.009 \\
\hline 1 & 175 & 27.7 & 9.7 & 2.47 & & \\
\hline$\geq 2$ & 456 & 72.3 & 4.2 & 1 & & \\
\hline Maternal schooling (years) & & & & & $0.38-2.34$ & 0.91 \\
\hline$<8$ years of study & 112 & 17.9 & 5.4 & 0.95 & & \\
\hline$\geq 8$ years of study & 515 & 82.1 & 5.6 & 1 & & \\
\hline Father's schooling (years) & & & & & $0.58-3.69$ & 0.41 \\
\hline$<8$ years of study & 68 & 13.1 & 8.8 & 1.46 & & \\
\hline$\geq 8$ years of study & 453 & 86.9 & 6.2 & 1 & & \\
\hline Family income (minimum & & & & & $0.86-3.49$ & 0.11 \\
\hline \multicolumn{7}{|l|}{ wage)* } \\
\hline$<1$ & 293 & 47.0 & 7.2 & 1.74 & & \\
\hline$\geq 1$ & 330 & 53.0 & 4.2 & 1 & & \\
\hline
\end{tabular}

*Value in the period of study $\mathrm{R} \$ 510.00$ reais. 


\section{Table 2}

Prevalence and Odds Ratio (OR) of excess weight according to variables in preschool children attended in full-time at day care center $(n=664)$ in Vitória da Conquista, Bahia, Brazil, 2010 to 2012.

\begin{tabular}{|c|c|c|c|c|c|c|}
\hline Variable & $\mathbf{N}$ & $\%$ & Excess weight (\%) & OR gross & $\mathrm{Cl} 95 \%$ & $p$ \\
\hline Age (years) & & & & & $0.32-1.61$ & 0.43 \\
\hline 24 I- 36 months & 176 & 26.5 & 4.5 & 0.72 & & \\
\hline $36|-| 60$ months & 488 & 73.5 & 6.1 & 1 & & \\
\hline Gender & & & & & $0.49-1.82$ & 0.87 \\
\hline Male & 340 & 51.2 & 5.6 & 0.95 & & \\
\hline Female & 324 & 48.8 & 5.9 & 1 & & \\
\hline Ethnicity & & & & & $0.44-1.72$ & 0.70 \\
\hline Non-White & 370 & 58.6 & 5.4 & 0.87 & & \\
\hline White & 261 & 41.4 & 6.1 & 1 & & \\
\hline Type of delivery & & & & & $1.27-4.98$ & 0.008 \\
\hline Cesarean & 159 & 25.3 & 10.1 & 2.5 & & \\
\hline Vaginal & 470 & 74.7 & 4.3 & 1 & & \\
\hline Birth weight (g) & & & & & $0.21-2.48$ & 0.62 \\
\hline$\geq 4000$ & 23 & 4.0 & 4.3 & 0.73 & & \\
\hline$<4000$ & 545 & 96.0 & 6.1 & 1 & & \\
\hline Breastfeeding & & & & & $0.27-3.06$ & 0.88 \\
\hline No & 57 & 9.0 & 5.3 & 0.91 & & \\
\hline Yes & 574 & 91.0 & 5.7 & 1 & & \\
\hline Exclusive breastfeeding & & & & & $0.98-5.02$ & 0.05 \\
\hline \multicolumn{7}{|l|}{ duration (months) } \\
\hline$<4$ & 159 & 37.6 & 8.8 & 2.22 & & \\
\hline$\geq 4$ & 264 & 62.4 & 4.2 & 1 & & \\
\hline
\end{tabular}




\section{Table 3}

Prevalence and Odds Ratio $(O R)$ of excess weight according to variables related to children attended in full-time at day care center $(n=664)$ in Vitória da Conquista, Bahia, Brazil, 2010 to 2012.

\begin{tabular}{|c|c|c|c|c|c|c|}
\hline Variable & $\mathbf{N}$ & $\%$ & Excess weight (\%) & OR gross & $\mathrm{Cl} 95 \%$ & $p$ \\
\hline Type of day care & & & & & $0.31-1.27$ & 0.20 \\
\hline Affiliated & 276 & 41.6 & 4.3 & 0.63 & & \\
\hline Municipal & 388 & 58.4 & 6.7 & 1 & & \\
\hline Time of day care (month) & & & & & $0.22-1.12$ & 0.89 \\
\hline$\leq 12$ & 223 & 33.9 & 3.6 & 0.50 & & \\
\hline$>12$ & 434 & 66.1 & 6.9 & 1 & & \\
\hline Adequacy of energy intake & & & & & $0.76-2.81$ & 0.26 \\
\hline$>100 \%$ recommendation & 291 & 43.8 & 6.9 & 1.46 & & \\
\hline$\leq 100 \%$ recommendation & 373 & 56.2 & 4.8 & 1 & & \\
\hline Adequacy of lipids intake & & & & & $0.58-2.16$ & 0.74 \\
\hline$>100 \%$ recommendation & 297 & 44.7 & 6.1 & 1.12 & & \\
\hline$\leq 100 \%$ recommendation & 367 & 55.3 & 5.4 & 1 & & \\
\hline Adequacy of carbohydrate intake & & & & & $0.73-2.74$ & 0.31 \\
\hline$>100 \%$ recommendation & 331 & 49.8 & 6.6 & 1.41 & & \\
\hline$\leq 100 \%$ recommendation & 333 & 50.2 & 4.8 & 1 & & \\
\hline Adequacy of protein intake & & & & & $0.57-2.84$ & 0.55 \\
\hline$>100 \%$ recommendation & 497 & 74.8 & 6.0 & 1.28 & & \\
\hline$\leq 100 \%$ recommendation & 167 & 25.2 & 4.8 & 1 & & \\
\hline
\end{tabular}

Table 4

Final model of the determinants for excesse weigth in children attended in day care centers in Vitória da Conquista, BA, $2010-2012$.

\begin{tabular}{lcc}
\hline Variable & OR gross & Cl95\% \\
\hline $\begin{array}{l}\text { Type of delivery } \\
\quad \text { Cesarean }\end{array}$ & 2.59 & $1.11-6.01$ \\
$\quad$ Vaginal & 1 & 0.03 \\
Number of children & 3.32 & 1 \\
$\quad 1$ & 0.005 \\
$\geq 2$ & $1.44-7.67$ \\
Exclusive beastfeeding duration & 0.03 \\
(months) & 2.59 \\
$\quad<4$ & 1 \\
\hline
\end{tabular}




\section{Discussion}

The prevalence of EW (5.7\%) observed in this study is consistent with the National Survey of Demographics and Health of Children and Women 20 which estimated prevalence of EW in Brazilian children between $5 \%$ and $7 \%$. However, it appeared superior than the Chamada Nutricional made in children from the Brazilian semiarid, which prevalence in Bahia State was 3.5\%.21 In Pernambuco State, the prevalence of EW in 954 preschool was $8.1 \%$ and $9 \%$ for Recife metropolitan region. 22

The results of the present study show an association between the type of delivery and childhood EW, wich children born by cesarean delivery presented 2.59 times (IC95\%: 1.11; 6.01) more chances than children born to vaginal delivery. Similar results was found for Huh et al.23 to analyzed a sample with 1225 children born in a health center in the United States, children's born by surgical delivery presented 2.10 (95\% CI: $1.36,3.23)$ times the chance to having EW. The mechanism of this association is not elucidated. A study released by Bellone et al.24 was found ghrelin (a orexigenic peptide control satiety) higher levels in 93 full term newborns by vaginal delivery (380.0; 300.0-445.0 pg/mL) when compared cesarean section. (310.0;202.0-393.0 pg/ml), $p<0.03$, however, the authors inform the need of more studies to know the mechanisms that lead to this difference. Other factor associated to EW in children born by cesarean would be attributed the difference in the intestinal microbiota composition. Faecal samples from children born by cesarean section presented a lower count of Bifidobacteria spp, Bacteroidetes and a higher proportion of Firmicutes bacteria. A similar bacterial profile have been found on intestinal microbiota in obese adults. ${ }^{25}$

In this study, the exclusive breastfeeding less than four months was associated with EW. WHO recommends an exclusive breastfeeding until six months of years, since 2001. ${ }^{26}$ However, studies who analyzed the protective effect of exclusive breastfeeding in children overweight and obesity showed different measures. A study carried out with preschool children in the city of Recife, Pernambuco found that overweight was more prevalent among children who received exclusive breastfeeding for less than four months $(22.5 \%)$ than those received exclusive breastfeeding for four months or more $(13.5 \%),(p=0.03) .^{3}$

A publication data of National Demographic and Health Survey of Children and Women 2006, included children with less than two years old and attending preschool, having not found association between exclusive breastfeeding for less than five months and obesity. 3,27

Other variable that show association with EW was to be singletons, with 3.33 times (IC95\%: 1.44; 7.67) chances to have EW on studied group. This results is consistent to anothers studies which also found more than risk of EW in singletons. 16,28 This association is explained by the fact of a greater number of children implies a greater division of family income, therefore, singletons would present a greater possibility for acquisition to preferred products with high energetic density. ${ }^{29}$ It is emphasized that the excessive mother's concern with child care and the persistence of the belief that child feeding is directly related to weight gain. 30

It was not found association between $\mathrm{EW}$ and socioeconomic, family income, father's schooling variables, demonstrating that this problem is present independent socioeconomic conditions in families.

The present study did not find association between birth weight equal or more than $4.0 \mathrm{~kg}$ and EW, unlike another study observed this relation and mentioned that the nutritional situation intrauterine, reflected by the birth weight, is a important determinant not only for childhood survival but also of overweight at preschool and school.18

This is a pioneer study regarding evaluation of the relationship between amount of energy and macronutrients offered in day care centers and their relation to EW in preschoolers. However, it did not find association between these variables. It is emphasized that this study evaluated only the food offered in the day care centers, and did not consider the food consumption in the residences nor evaluated the quality of the diet about the consumption of fresh and processed foods. The design of the present study is a cross-sectional, which presents a limitation the establishment of a temporal relationship between some variables of exposure with the outcome and, therefore, it is not possible to infer a cause and effect relationship for the associations observed.

This study concludes that EW represents a relevant nutritional disorder among preschool children studied. For reducing and/or preventing EW in this population, it is important that interventions begin in prenatal care, through the guideline of health professionals regarding the importance of exclusive breastfeeding, as well as stimulation of vaginal delivery. In addition, it is emphasized the importance of nutritional orientations directed to families with singletons. The encouragement of vaginal delivery, breastfeeding and nutritional guidelines are simple measures that can be performed at health facilities 
during both prenatal and growth, as well as development visits with educational activities for groups. It is expected that the reduction of childhood EW can positively impact the prevention of cardiovascular diseases and diabetes mellitus in adults, which consume a significant amount of public health resources.

\section{References}

1. Onis M, Blössner M, Borghy E. Global prevalence and trends of overweight and obesity among preschool children. Am J Clin Nutr. 2010; 92 (5): 1257-64.

2. Moreira AM, Cabral PC, Ferreiras HS, Lira PI. Overweight and associated factors in children from northeasten Brazil. J Pediatr. 2012; 88 (4): 347-52.

3. Silveira JA, Colugnati FA, Cocetti M, Taddei JA. Secular trends and factors associated with overweight among Brazilian preschool children: PNSN-1989, PNDS-1996, and 2006/07. J Pediatr. 2014; 90(3): 258-66.

4. Oppitz IN, Cesar JA, Neumann NA. Excesso de peso entre menores de cinco anos em municípios do semiárido. Rev Bras Epidemiol. 2014; 17 (4): 860-72

5. Müller RM, Tomasi E, Facchini LA, RX Piccini, Silveira DS, Siqueira FV, Thumé E, Silva SM, Dilélio AS. Excesso de peso e fatores associados em menores de cinco anos em populações urbanas no Brasil. Rev Bras Epidemiol. 2014; 17 (2): 285-96

6. Moreira MA, Cabral PC, Ferreira HS, Lira PIC. Prevalence and factors associated with overweight and obesity in children under five in Alagoas, Northeast of Brazil; a population-based study. Nutr Hosp. 2014; 29 (6): 1320-6.

7. Robinson SM, Crozier SR, Harvey NC, Barton BD, Law CM, Godfrey KM, Cooper C, Inskip HM. Modifiable earlylife risk factors for childhood adiposity and overweight: an analysis of their combined impact and potential for prevention. Am J Clin Nutr. 2015; 101: 368-75.

8. Yamakawa $M$, Yorifuji $\mathrm{T}$, Inoue $\mathrm{S}$, Kato $\mathrm{T}$, Doi $\mathrm{H}$. Breastfeeding and Obesity Among Schoolchildren: A Nationwide Longitudinal Survey in Japan. JAMA Pediatr. 2013; 167(10): 919-25.

9. Weng SF, Redsell SA, Swift JA, Yang M, Glazebrook CP. Systematic review and meta-analyses of risk factors for childhood overweight identifiable during infancy. Arch Dis Child. 2012; 97(12): 1019-26.

10. IBGE Cidades. 2010 [acessado em 14 jun 2014]. Disponível em: http://cidades.ibge.gov.br/xtras/ perfil.php?codmun=29330.

11. Brasil. Ministério da Saúde. Orientações para coleta e análise de dados antropométricos em serviços de saúde: norma técnica do sistema de Vigilância Alimentar e Nutricional - SISVAN. Brasília, DF; 2011.

12. WHO (World Health Organization). WHO Anthro for personal computers: software for assessing growth and development of the world's children (version 3.2.2). Geneva, Switzerland: 2007. [acesso em 15 abr 2014] Disponível em: http://www.who.int/ childgrowth/software/en/.

13. WHO (World Health Organization). WHO Child Growth
Standards: Length/height-for-age, weight-for-age, weightfor-length, weight-for-height and body mass index-for-age. Methods and development. WHO (nonserial publication). Geneva: WHO; 2006.

14. Brasil. Ministério da Educação. Resolução/CD/FNDE n ${ }^{\circ}$ 26, de 17 de Junho de 2013. Dispõe sobre o atendimento da alimentação escolar aos alunos da educação básica no âmbito do Programa Nacional de Alimentação Escolar PNAE. Coleção de Leis do Fundo Nacional de Desenvolvimento da Educação, Brasília, DF 2013; 44: 39p.

15. Vitolo MR, Gama CM, Bortolini GA, Campagnolo PDB, Drachler ML. Some risk factors associated with overweight, stunting and wasting among children under 5 years old. J Pediatr. 2008; 84 (3): 251-7.

16. Novaes JF, Lamounier JA, Franceschini SCC, Priore SE. Fatores ambientais associados ao sobrepeso infantil. Rev. Nutr. 2009; 22(5): 661-673. doi: 10.1590/S141552732009000500007.

17. Menezes CFB, Neves J, Gonsalez PS, Vasconcelos FAG. Incidence of overweight/obesity in preschool children during a two-year follow-up. Rev Nutr. 2014; 27 (3): 26978.

18. Zhou L, He G, Zhang J, Xie R, Walker M, Wu Wen S. Risk factors of obesity in preschool children in an urban area in China. Eur J Pediatr. 2011; 170 (11): 1401-6.

19. Balaban G, Silva GAP, Dias MLCM, Dias MCM, Fortaleza GTM, Morotó FMM, Rocha ECV. O aleitamento materno previne o sobrepeso na infância? Rev. Bras. Saúde Matern. Infant. 2004; 4 (3): 263-8.

20. Brasil. Ministério da Saúde. Pesquisa Nacional de Demografia e Saúde da Criança e da Mulher. PNDS 2006: Banco de dados. Brasília, DF: Ministério da Saúde; 2009 [acesso em 10 Mai 2014]. Disponível em: http: //bvsms.saude.gov.br/bvs/pnds/bancodados.php

21. Ferreira S, Assunção ML, Florêncio TMMT, Lima MAA. Estado Nutricional De Pré-Escolares da Região Semiárida do Estado de Alagoas 2005. In: Chamada Nutricional: um Estudo Sobre a Situação Nutricional de Crianças do Semiárido Brasileiro. Desenvolvimento Social em Debate. Cadernos de Estudos No. 4. Ministério do Desenvolvimento Social e Combate a Fome. Brasília, DF; 2006. p. 37-42.

22. Menezes RCE, Lira PIC, Oliveira JS, Leal VS, Santana SCS, Andrade SLLS, Batista Filho, M. Prevalência e determinantes do excesso de peso em pré-escolares. J Pediatr. 2011; 87 (3): 231-7.

23. Huh SY, Rifas-Shiman SL, Zera CA, Edwards JW, Oken E, Weiss ST, Gillman MW. Delivery by caesarean section and risk of obesity in preschool age children: a prospective cohort study. Arch Dis Child. 2012; 97: 610-6. 
24. Bellone S, Rapa A, Vivenza D, Vercellotti A, Petri A, Radetti G, Bellone J, Broglio F, Ghigo E, Bona G. Circulating ghrelin levels in newborns are not associated to gender, body weight and hormonal parameters but depend on the type of delivery. J. Endocrinol. Invest. 2003; 26(4): RC9-RC11.

25. Ajslev TA, Andersen CS, Gamborg M, Sorensen TIA, Jess T. Childhood overweight after establishment of the gut microbiota: the role of delivery mode, pre-pregnancy weight and early administration of antibiotics. Int J Obes. 2011; 35 (4): 522-9.

26. WHO (World Health Organization). Expert Consultation on Optimal Duration of Exclusive Breastfeeding. Geneva: march 2001.

27. Cocetti M, Taddei JAJC, Konstantyner T, Konstantyner TCRO, Barros Filho AA. Prevalence and factors associated with overweight among Brazilian children younger than 2 years. J Pediatr (Rio J). 2012; 88 (6): 503-8
28. Hunsberger M, Formisano A, Reisch LA, Bammann K, Moreno L, Henauw S, Molnar D, Tornaritis M, Veidebaum T, Siani A, Lissner L. Overweight in singletons compared to children with siblings: the IDEFICS study. Nutrition and Diabetes. 2012; 2 (7): 1-3. doi:10.1038/nutd.2012.8

29. Oliveira AMA, Cerqueira EMM, Souza JS, Oliveira AC. Sobrepeso e Obesidade Infantil: Influência de Fatores Biológicos e Ambientais em Feira de Santana, BA. Arq Bras Endocrinol. Metab. 2003; 47 (2): 145-2.

30. Haugaard LK, Ajslev TA, Zimmermann E, Ängquist L, Sørensen TIA. Being an Only or Last-Born Child Increases Later Risk of Obesity. PLoS ONE. 2013; 8 (2): 1-8.

Received on July 14, 2016

Final version submitted on March 13, 2017

Approved on March 24, 2017 